\title{
Brands in a Digital Society \\ デジタル社会におけるブランドのあり方
}

\author{
Satoru Shibuya ${ }^{* 1}$ \\ 副編集委員長 / 学習院大学 国際社会科学部 \\ 涉谷覚
}

${ }^{* 1}$ Deputy Editor-in-Chief and Faculty of International Social Sciences, Gakushuin University, satoru.shibuya@gakushuin.ac.jp

\begin{abstract}
The chief theme of this issue is the terms "Digital" and "brand," based on our fundamental question of how brands are growing under the current digital environment. Consistent with this theme, we would like to consider two recent upheavals with respect to brands. The first is so-called "Core Marketing," which advocates focusing on core customers who account for approximately 80 percent of total sales, based on the Pareto principle. This is quite persuasive, if the underpinning assumption is right. However, Sharp (2010) has recently reported that in most industries, these core customers are responsible for only about fifty percent of a brand's sales. If this is correct, the fundamental logic of fan marketing is compromised. The second upheaval relates to the emergence of many "Digital Native Vertical Brands (DNVB)", such as WP, Bonobos, Everlane, Glossier, etc. Our question is: from the perspective of the relationship between brands and their customers, what are the key differences between these DNVB and traditional brands? Our contributors to this issue discuss these highly important concerns.
\end{abstract}

\section{本号の特集テーマについて}

本号の特集テーマは当初「デジタル・マーケティングとブランド」としたが，このままではやや狭すぎ るため,「デジタル社会において，ブランドのあり方とはどのようなものか」と広く問い直すこととした。 この問題意識に照らして, 以下では近年のブランドをめぐる議論の中で気になる論点を $2 つ$ 取り上げ, これらと関連させつつ本号に掲載した各論文を紹介したい。

\section{論点 1 : コアマーケティングとパレートの法則}

広告の効果が低下していることなどを背景に, 新規顧客獲得のために不特定多数に向けてマスマーケティ ングを行う発想が時代遅れであることを啓蒙し, 特定少数の熱心なファンに向けたコミュニケーション施 策の重要性を説く論調が多く見られる。そうした文脈では, 熱狂する顧客, 顧客の熱量, コア・ファンな どの用語がしばしば用いられる。そこで以下では仮に，これらにおいて主張されるマーケティングを仮に 「コアマーケティング」と呼ぶことにしよう。

コアマーケティングが今日のブランドにまさに必要とされているものであることには疑いの余地がない。 しかしこうした主張の多くがその論拠として,「少数のコア顧客が大部分の売上げをもたらす」という経験 則をあげる点には，やや注意を要する。

周知のようにこの経験則はパレートの法則とも呼ばれ, 典型的には「上位 $20 \%$ 顧客による売上げが全 体の $80 \%$ 占める」などの内容をとる。つまりコアマーケティングとは, パレートの法則がゆえに, 少数 のコア顧客に濃いコミュニケーションを行うことで効果的なマーケティングを行いつつ, 売上げの大部分 
を維持することができるという主張である。前提となるパレートの法則が成立するなら，このようなコア マーケティングはきわめて適切な戦略である。

これに対して Sharp（2010）では，多くの業界における多くのブランドに扔いてパレートの法則が成り 立たず，上位顧客がもたらす売上げは全体の半分程度に過ぎないことを，豊富なデータとともに示してい る。このようにパレートシェアが低い業界では，上位顧客のみに集中するコアマーケティングは下位顧客 による半分の売上げの喪失につながるため，現実的ではない。

企業が不特定多数に向けたマーケティングを「いまだに」実施している場合，それは依然として古いマ スマーケティングの発想から抜け出せていないからではなく，それらの業界では売上げの半分をもたらす 下位顧客を捨てることが現実的ではないからかもしれない。ただしこの場合も下位顧客に向けたマスマー ケティングだけでは不十分なのであり，もう半分の売上げをもたらす上位顧客（コア顧客）に向けたマー ケテイングも，同時に行うべきであることは言うまでもない。

このようにパレートの法則が成り立たない場合, 企業は特定少数のコア顧客に向けたマーケティングと, 不特定多数のマス顧客に向けたマスマーケティングとを，ともに並行して行う必要がある。その際に，こ れら 2 つのマーケティングは相互に独立した全く別々の施策として行われるべきなのか，あるいは両者を 関連づけることができるのか，は 1 つの素朴な問いである。企業としては，少数のコア顧客に向けた取り 組みが，その他の不特定多数のマス顧客に波及してくれれば理想的である。実際に，コアマーケティング を説く論調の多くは，このようなコア顧客からマス顧客へと伝わる波及効果への期待に言及することが多 い。ここに，デジタル時代のブランドを巡る1つの論点がある。

\section{西原・圓丸・鈴木論文}

西原・圓丸・鈴木論文は，企業が一方向的にブランド構築を行っていた「ブランド価值説得」のパラダ イムから，企業と消費者がともにブランドを作り上げる「ブランド価值共創」のパラダイムを経て，新た に「ブランド価值協創」のパラダイムを提示している。同パラダイムは，ブランドをもつ企業と消費者以 外に，ブランド構築に寄与する第三者（BIT: Brand Incubation Third-party）に光を当てる。従来のパラダイ ムではこのような BIT の役割が見落とされてきた（またはノイズと見なされてきた）と述べており，きわ めて重要な指摘である。西原らはBIT の例として,「カリモク 60」のケースに抢ける社外デザイナー, カ フェ,インテリア雑誌等をあげている。

この論文は，上記の「コア顧客か，マス顧客か」という議論にも1つの示唆を与えてくれる。それは, ブランドを有する企業がコアマーケティングによって密なコミュニケーションをとりつつ協働すべき相手 は，コア顧客だけではなく，ブランド構築プロセスに寄与する多様な BIT を含めるべきということであ る。多くのBIT を巻き込んで行くことにより，各BITについているさまざまな別種のコア顧客をも，さら にブランドに巻き込んで行くことができる。こうした多様なBIT と多様なコア顧客を取り込んだ取り組み は, 自社の既存のコア顧客のみに集中する従来の施策に比べて, より多様なルートを通じて, その周囲に 広がる不特定多数のマス顧客へとつながる可能性を切り開く。

\section{論点 2 : デジタル発のブランドは既存ブランドと異なるか}

「デジタル発のブランド」とがDNVB”（Digital Native Vertical Brand：デジタルネイティブ世代の直販ブ 
ランド）などと称されるブランドが次々に生まれ，若い世代を中心とするファンにもて碎されている。こ れらには，メガネの WP (ワービーパーカー)，衣料品のボノボスやエバーレーン，あるいは化粧品のグ ロッシアー，女性用下着のライブリーなど，枚挙にいとまがない。

D2C（ダイレクト・トゥ・コンシューマー）と呼ばれるビジネスモデルを採用するこれらのブランドと その熱心な顧客層との関係のあり方が，デジタル社会以前から長きにわたって築き上げられてきた既存ブ ランドに扔けるそれと異なるのか否かは，今後のブランドのあり方を占う上できわめて重要な論点である。

\section{久保田論文}

本号に掲載した 2 編の久保田論文は，このようなデジタル社会の消費者行動およびブランドのあり方に ついて，きわめて重要な示唆を与えてくれる。久保田は，デジタル技術が浸透する今日の社会に特有の消 費行動を，短命で，所有よりアクセスを重視し，脱物質的傾向が強い「リキッド消費」と位置づけた先行 研究を引用しつつ，そのような時代に扩けるブランドのあり方について議論を展開している。

この論文で示されているデジタル時代の新たなブランド消費の特徵は，広くブランド全般にあてはまる ものであろうが，上に見た「デジタル発」の新興ブランドにおいて，より鮮明に現れる可能性が高い。こ のような意味で，久保田論文はこれからのデジタル社会における消費者行動のあり方，これに対応した既 存および新興のブランドのあり方について，きわめて重要な示唆を与えてくれる。

\section{田中論文}

田中論文は，より根本的な視点に立ち戻り，ブランドにおいて想像力が果たす役割を議論する。田中は 想像力とは「ここに無いものを思い浮かべる」能力であるとし，ブランドがブランドとしての働きを発揮 するために, 本質的に重要な役割を担っていると述べる。このような問題意識から, 同論文ではマーケティ ング論はもとより哲学，心理学，精神医学，脳神経科学，人類学などの広範な先行研究を見渡し，想像力 とは何かを根本から考察する。

そしてこれらを踏まえて,「交換の対象としての商品・企業・組織に関して顧客が想像力を駆動して働か せる認知システムとその知識」という新たなブランドの定義を提示している。またこの定義にもとづいて, 想像力の役割を中核に組み込んだブランドと消費者行動の新たなモデルを提示し，またこれにもとづいた 新たなブランドの研究パラダイムを提唱している。

本号に掲載した田中論文は，Tanaka（2017）（邦題『ブランド戦略論』有斐閣）では論じられなかったブ ランドにおける想像力の役割に焦点を当てる，非常にスケールの大きな論考となっている。

\section{久保論文}

ここまで紹介した 4 論文が，いずれも概念的な議論を展開するものであるのに対して，久保論文は実証 研究である。同論文は, デジタル社会においてきわめて重要な役割を果たす $\mathrm{EC}$ サイトやアプリにおける ユーザーエクスペリエンスが, ブランドに及ぼす影響を調査した。

社会のデジタル化が進み，日常生活にデジタルが浸透するほど，デジタル世界と物理的な世界との接点 を構成するユーザーインターフェースと，その経験であるユーザーエクスペリエンスはますますその重要 
性が増す。久保は, 特にデジタル環境下のユーザーエクスペリエンスに関する欧米の先行研究を詳細にレ ビューした上で，日本ではそうした研究がそしいことを指摘する。その上で楽天と Amazon を対象として 「便利か」「使いやすいか」「好ましいか」など 6 項目がブランド態度に及ぼす影響を調査している。

同論文は，ユーザーエクスペリエンスに関する広範な先行研究をまとめたことにも高い価值がある。そ の上で従来あまり注目されてこなかった国内 EC サイトにおけるユーザーエクスペリエンスに関して, 実 証研究を通じて議論を先に進めるものであり，実務および研究の両面で，その貢献はきわめて大きい。

\section{終わりに}

以上のように本号の特集論文では，ますますデジタル化が急速に進む今日の社会において，ブランドの マネジメントやブランドに関する消費者行動がどのように変化していくのかが, さまざまな角度から議論 されている。これらが今後のブランドを巡る実務および研究において，大いに貢献することを願ってやま ない。

\section{References}

Sharp, B. (2010). How brands grow: What marketers dont know. New York: Oxford University Press. (加藤巧（監修) · 前平謙二（訳）（2018）。『ブランディングの科学一誰も知らないマーケティングの法則 11』朝日新聞出版）

Tanaka, H. (2017). Integrated brand strategy: Theory, practice \& cases. Tokyo: Yuhikaku.（田中洋（2017).『ブランド戦 略論』有斐閣）（In Japanese） 